OPEN ACCESS

Edited by:

Maria Schirone,

University of Teramo, Italy

Reviewed by:

Zhao Chen,

Clemson University, United States

Alexandra Lianou,

Agricultural University of Athens,

Greece

Dario De Medici,

Istituto Superiore di Sanità, Italy

*Correspondence:

Bariinder P. Kaur

barjinderpkaur@gmail.com

Specialty section This article was submitted to

Food Microbiology,

a section of the journal

Frontiers in Microbiology

Received: 06 December 2016 Accepted: 28 June 2017

Published: 24 July 2017

Citation:

Kaur BP and Rao PS (2017) Modeling the Combined Effect of Pressure and Mild Heat on the Inactivation Kinetics of Escherichia coli, Listeria innocua, and Staphylococcus aureus in Black

Tiger Shrimp (Penaeus monodon).

Front. Microbiol. 8:1311.

doi: $10.3389 /$ fmicb.2017.01311

\section{Modeling the Combined Effect of Pressure and Mild Heat on the Inactivation Kinetics of Escherichia coli, Listeria innocua, and Staphylococcus aureus in Black Tiger Shrimp (Penaeus monodon)}

\author{
Barjinder P. Kaur ${ }^{1 *}$ and P. Srinivasa Rao ${ }^{2}$ \\ ${ }^{1}$ Department of Food Engineering, National Institute of Food Technology Entrepreneurship and Management, Sonepat, India, \\ ${ }^{2}$ Agricultural and Food Engineering Department, Indian Institute of Technology Kharagpur, Kharagpur, India
}

The high-pressure inactivation of Escherichia coli, Listeria innocua, and Staphylococcus aureus was studied in black tiger shrimp (Penaeus monodon). The processing parameters examined included pressure ( 300 to $600 \mathrm{MPa})$ and temperature $\left(30\right.$ to $\left.50^{\circ} \mathrm{C}\right)$. In addition, the pressure-hold period (0 to $15 \mathrm{~min}$ ) was investigated, thus allowing both single-pulse pressure effects (i.e., zero holding time) and pressure-hold effects to be explored. E. coli was found to be the most sensitive strain to single-pulse pressure, followed by $L$. innocua and lastly $S$. aureus. Higher pressures and temperatures resulted in higher destruction rates, and the value of the shape parameter $\left(\beta^{\prime}\right)$ accounted for the downward concavity $\left(\beta^{\prime}>1\right)$ of the survival curves. A simplified Weibull model described the non-linearity of the survival curves for the changes in the pressure-hold period well, and it was comparable to the original Weibull model. The regression coefficients $\left(R^{2}\right)$, root mean square error (RMSE), accuracy factor $\left(A_{f}\right)$, bias factor $\left(B_{f}\right)$, and residual plots suggested that using linear models to represent the data was not as appropriate as using non-linear models. However, linear models produced good fits for some pressure-temperature combinations. Analogous to their use in thermal death kinetics, activation volume $\left(V_{a}\right)$ and activation energy $\left(E_{a}\right)$ can be used to describe the pressure and temperature dependencies of the scale parameter $\left(\delta\right.$, min), respectively. The $V_{a}$ and $E_{a}$ values showed that high pressure and temperaturefavored the inactivation process, and $S$. aureus was the most baro-resistant pathogen.

Keywords: black tiger shrimp, high-pressure processing, inactivation, pathogens, weibull, log-linear

\section{INTRODUCTION}

High-pressure processing (HPP) offers an attractive alternative to heat pasteurization as a means to produce preservative-free, microbiologically safe, and stable foods (Pavuluri and Kaur, 2014). Over the last decade, significant progress has been made in the high-pressure pasteurization of foods, and several commercial products treated with HPP are now available on the market in several countries (Balasubramaniam et al., 2008). The high level of interest in this novel technology is due 
to its ability to destroy or inactivate foodborne microorganisms and enzymes in food with minimal change in the organoleptic properties and nutritional quality of the food. Pressures ranging from 300 to $600 \mathrm{MPa}$ can inactivate most pathogenic and spoilage vegetative cells, yeasts, and molds (Smelt, 1998). Moreover, it is economically beneficial to use lower pressure in combination with mild heat $\left(30-50^{\circ} \mathrm{C}\right)$ (Buzrul et al., 2008).

For effective use of high-pressure technology for food preservation, it is necessary to study the interactions between the processing parameters (pressure, time, and temperature) and to determine the optimum conditions for obtaining desirable levels of microbial destruction while maintaining a high degree of nutritional quality and good flavor and texture (Kaur and Rao, 2016).

Several studies have demonstrated the efficacy of HPP for inactivating a wide spectrum of Gram-negative and Grampositive bacteria in suspensions, as well as in solid food items. HPP inactivates microorganisms by acting against multiple targets, including intracellular and membrane-bound enzymes (Wouters et al., 1998). However, the rate and pattern of HPP-induced microorganism inactivation is quite variable and influenced by the processing conditions, medium composition, and microorganism type/strain. Therefore, there is a need for accurate prediction of the inactivation behavior of foodborne microorganisms, as well as accurate characterization of their resistance to HPP. Kinetic modeling is helpful for determining the most efficient processing parameters and for the prediction of the HPP effects on microbial inactivation and product shelflife. It is also an effective way of carrying out a risk assessment and simulation of the HPP process (Smelt et al., 2002).

Although simple first-order-type inactivation curves do sometimes occur for pressure-treated cells (Basak et al., 2002; Riahi et al., 2003; Dogan and Erkmen, 2004; Ramaswamy et al., 2008), significant deviations from linearity (such as, sigmoidal curves, curves with shoulders, and tailing) have been reported by multiple researchers (Garriga et al., 2002; Chen and Hoover, 2003; Buzrul and Alpas, 2004; Rajan et al., 2006; Ahn et al., 2007; Rendueles et al., 2011). A number of models have been proposed to describe these non-linear survival curves, such as, the Baranyi, Weibull, modified Gompertz, log-logistic, and quasi-chemical models. Among these models, the most simple and flexible is the Weibull model, and it is reported to fit the experimental data better than the other models (Panagou et al., 2007; SermentMoreno et al., 2014).

Black tiger shrimp (Penaeus monodon) is a commercially important shrimp species, persistently in demand in the global market due to its distinct flavor, texture, and high nutritional value (Pushparajan and Soundarapandian, 2010). In past decades, there have been many issues associated with shrimp exported from India due to high bacteria counts and the presence of pathogenic bacteria such as, E. coli and Listeria monocytogenes. $L$.

Abbreviations: HPP, High-pressure processing; $E_{a}$, Activation energy; $\mathrm{MPa}$, Megapascal; $N_{0}$, Initial microbial counts in the control samples; $N_{P E}$, Number of cells that survived after single-pulse pressurization; $N_{t}$, Number of cells that survived after pressure treatment for time $t(\mathrm{~min})$; SPPE, Single-pulse pressure effect; $V_{a}$, Activation volume. monocytogenes is particularly problematic for the food industry as it is widespread in the environment and can grow in a broad range of temperatures (Jofré et al., 2009). Crustaceans have also been linked with food poisoning attributed to $S$. aureus because of the ubiquity of this organism in the processing environment combined with the degree of handling required for processing these food types (Nicolaides, 2009).

Thus, the present study was undertaken with the aim of investigating the inactivation kinetics of E. coli O157:H7 ATCC 43895 (a Gram-negative bacterium) and two Gram-positive bacteria, namely L. innocua ATCC 33090 (a nonpathogenic indicator microorganism for L. monocytogenes) and S. aureus ATCC 29213, in black tiger shrimp at various pressuretemperature $(P-T)$ combinations. These three foodborne pathogens have been reported to be resistant to pressure treatment (Guan et al., 2006; Buzrul et al., 2008; Ruiz-Espinosa et al., 2013).

\section{MATERIALS AND METHODS \\ Preparation of Bacterial Cultures}

Pure cultures of E. coli O157:H7 ATCC 43895, L. innocua ATCC 33090, and S. aureus ATCC 29213 were procured in freezedried form from Merck Ltd India. The bacteria were activated by inoculating tryptic soy broth supplemented with $0.6 \%$ yeast extract (TSBYE) (product number: M011; Himedia Laboratories, India) with each of the pure cultures, and they were then incubated at $37^{\circ} \mathrm{C}$ for $24 \mathrm{~h}$. Stock cultures were prepared by mixing the activated cultures with sterilized $80 \%$ glycerol (v/v) in a 1:1 ratio in Eppendorf tubes, which were stored at $-40^{\circ} \mathrm{C}$ in a deep freezer until further analysis. The purity of the cultures was determined by Gram staining and microscopic observation. Each inoculum was prepared by inoculating $100 \mathrm{~mL}$ of sterile TSBYE with $1 \mathrm{~mL}$ of the thawed stock culture, and it was then incubated at $37^{\circ} \mathrm{C}$ for $24-30 \mathrm{~h}$ to obtain a count of $10^{9}$ colony-forming units (CFU) $\mathrm{mL}^{-1}$.

\section{Preparation and Inoculation of Samples}

Freshly harvested black tiger shrimp weighing 25-35g were obtained from Shankarpur coast, West Bengal, India, and transported to the laboratory within $4 \mathrm{~h}$ under chilled conditions (with a sample-to-ice ratio of 1:1). The shrimp were washed with chilled water, deheaded, and shelled. Before inoculation, the samples were tested for the presence of E. coli, Listeria, and S. aureus according to the method proposed by the APHA (2001), which is described later in Section Enumeration.

After ensuring the absence of these organisms, test samples were inoculated with the activated bacteria, according to the method described by Anang et al. (2007). Whole shrimp samples were dipped into each of the prepared inocula $\left(10^{9} \mathrm{CFU} \mathrm{mL} \mathrm{m}^{-1}\right)$ individually at room temperature $\left(27^{\circ} \mathrm{C}\right)$ for $15 \mathrm{~min}$. The ratio of sample to culture suspension was 1:2 (w/v), which allowed complete immersion of the samples. The initial bacterial cell counts in the shrimp samples after dipping were approximately $10^{7} \mathrm{CFU} \mathrm{g}^{-1}$. Thereafter, the samples were left to dry in a sterile cabinet for $1 \mathrm{~h}$. The inoculated samples were packed in ethylene vinyl alcohol films (thickness: $110 \pm 1.0 \mu \mathrm{m}$ ), with three 
shrimps per pouch. The samples were double packed to ensure no direct contact with the pressure-transmitting medium during the HPP.

\section{HPP}

The high-pressure treatment was performed in a lab-scale HPP unit (model: S-IL-100-250-09-W; Stansted Fluid Power Systems, $\mathrm{UK})$, with aqueous monopropylene glycol $30 \%(\mathrm{v} / \mathrm{v})$ as the pressure-transmitting medium. The samples were processed at four pressures, 300, 400,500, and $600 \mathrm{MPa}$, and four temperatures, $30,40,50$, and $60^{\circ} \mathrm{C}$. For each $P-T$ combination, the following six pressure-hold periods were investigated: 0 , $3,6,9,12$, and $15 \mathrm{~min}$. The single-pulse pressurization $(0-$ min holding time) involved pressurization of the sample to the desired level followed by immediate depressurization. The rate of pressurization was fixed at $300 \mathrm{MPa} \mathrm{min}-1$ and the depressurization was achieved in $<10 \mathrm{~s}$. After $P-T$ treatment, the pouches were kept at $4^{\circ} \mathrm{C}$ for $24 \mathrm{~h}$ to allow the pressurized cells to recover from the pressure stress effect before analysis. For each $P-T$ combination, three pouches (with three shrimp per pouch) were processed. The experiments were performed independently twice and, for each processing condition, three samples were analyzed.

\section{Enumeration}

Microbiological analyses were performed according to the method described by the APHA (2001). A 10-g sample was aseptically cut from each sample lot and macerated with $90 \mathrm{~mL}$ peptone water $(0.1 \%)$ in a sterile glass mortar. The homogenate was serially diluted using $0.1 \%$ sterile peptone water and plated onto appropriate culture media. For ease of handling, the direct pour plate method was adopted. E. coli was enumerated on Violet Red Bile Agar and L. innocua on Listeria-Selective Agar Base (PALCAM). The plates were incubated at $37^{\circ} \mathrm{C}$ for $24 \mathrm{~h}$ for $E$. coli and $48 \mathrm{~h}$ for $L$. innocua. To examine the surviving S. aureus populations, samples were inoculated on Baird Parker Agar and the plates incubated at $37^{\circ} \mathrm{C}$ for $48 \mathrm{~h}$. Black colonies with clear zones, which were presumed to be $S$. aureus, were counted.

\section{Kinetics Analysis}

The pressure-induced destruction of the microorganisms was analyzed in terms of the single-pulse pressure effect (SPPE) and the pressure-hold effect. First, the SPPE was determined by calculating the logarithmic difference between the initial microbial counts in the control samples $\left(N_{0}\right)$ and the number of cells that survived after single-pulse pressurization $\left(N_{P E}\right)$ as follows:

$$
S P P E=\log _{10}\left(N_{0}\right)-\log _{10}\left(N_{P E}\right)
$$

Second, a modified Weibull model (Equation 2; (Chakraborty et al., 2015)) was fitted to the data on survivor fractions corresponding to the different pressure-hold periods using Origin Pro version 8.0 (OriginLab Corporation, Northampton, MA, USA).

$$
\log _{10} \frac{N_{t}}{N_{P E}}=-\left(\frac{t}{\delta^{\prime}}\right)^{\beta^{\prime}}
$$

where $N_{t}$ is the number of microorganisms that survived after pressure treatment for time $t$ ( $\min ), N_{P E}$ is the number of cells that survived after single-pulse pressurization, and $\delta^{\prime}$ and $\beta^{\prime}$ represent the scale parameter ( $\left.\mathrm{min}\right)$ and shape parameter (dimensionless), respectively. $\beta^{\prime}<1$ denotes upward concavity, $\beta^{\prime}>1$ represents downward concavity, and $\beta^{\prime}=1$ corresponds to linear (first-order) kinetics. The concavity can be used to interpret the inactivation resistance of the bacterial population: (a) homogenous $\left(\beta^{\prime}=1\right)$, (b) increasing resistance $\left(\beta^{\prime}<1\right)$, or (c) decreasing resistance as a result of accumulated damage in the population $\left(\beta^{\prime}>1\right)$ (Serment-Moreno et al., 2014).

The best-fit values of $\delta^{\prime}$ and $\beta^{\prime}$ were determined for each species at each of the $P-T$ combinations. It has been reported that the shape parameter $\left(\beta^{\prime}\right)$ represents the microorganism behavior index (Fernandez et al., 2002). Therefore, within the ranges of the processing parameters evaluated in this study, for each species, $\beta$ was fixed at a uniform value using the method described by Chakraborty et al. (2015). In brief, for a pre-assumed value of $\beta^{\prime}$,

\begin{tabular}{|c|c|c|c|c|c|}
\hline \multirow[t]{2}{*}{ Bacterial species } & \multirow[t]{2}{*}{ Temperature $\left({ }^{\circ} \mathrm{C}\right)$} & \multicolumn{4}{|c|}{ Pressure (MPa) } \\
\hline & & 300 & 400 & 500 & 600 \\
\hline \multirow[t]{2}{*}{ E. coli } & 30 & $0.90 \pm 0.04^{\mathrm{aA}}$ & $1.15 \pm 0.03^{a A}$ & $1.56 \pm 0.10^{\mathrm{aA}}$ & $1.75 \pm 0.09^{\mathrm{aA}}$ \\
\hline & 40 & $2.74 \pm 0.09^{a B}$ & $3.17 \pm 0.11^{\mathrm{abB}}$ & $3.99 \pm 0.08^{\mathrm{bB}}$ & $4.29 \pm 0.17^{b B}$ \\
\hline \multirow[t]{2}{*}{ L. innocua } & 30 & $0.88 \pm 0.04^{\mathrm{aA}}$ & $1.09 \pm 0.06^{\mathrm{aA}}$ & $1.46 \pm 0.14^{\mathrm{aA}}$ & $1.58 \pm 0.08^{a A}$ \\
\hline & 40 & $2.65 \pm 0.15^{\mathrm{aB}}$ & $2.99 \pm 0.14^{\mathrm{aB}}$ & $4.01 \pm 0.23^{\mathrm{bB}}$ & $4.39 \pm 0.11^{b B}$ \\
\hline \multirow[t]{3}{*}{ S. aureus } & 30 & $0.75 \pm 0.05^{\mathrm{aA}}$ & $0.90 \pm 0.07^{\mathrm{aA}}$ & $1.23 \pm 0.05^{\mathrm{aA}}$ & $1.29 \pm 0.08^{\mathrm{aA}}$ \\
\hline & 40 & $2.09 \pm 0.14^{\mathrm{aB}}$ & $2.69 \pm 0.2^{\mathrm{abB}}$ & $3.73 \pm 0.09^{\mathrm{bB}}$ & $4.01 \pm 0.17^{\mathrm{bB}}$ \\
\hline & 50 & $4.39 \pm 0.11^{\mathrm{aC}}$ & $4.81 \pm 0.21^{a b C}$ & $5.19 \pm 0.25^{b C}$ & $5.61 \pm 0.20^{b C}$ \\
\hline
\end{tabular}

TABLE 1 | Estimated PE values (Log PE) for E. coli, L. innocua and S. aureus in black tiger shrimp.

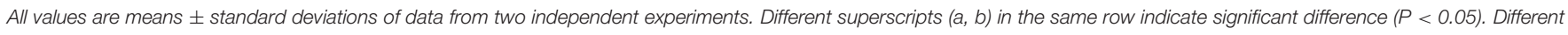
superscripts $(A, B, C)$ in the same column indicate significant difference $(P<0.05)$. 
the $\delta^{\prime}$ values were calculated using Equation (3) for the five nonzero pressure-hold periods (with three replications for each $P-T$ combination).

$$
\delta^{\prime}=\left[\frac{t}{\left\{-\log _{10}\left(\frac{N_{t}}{N_{P E}}\right)^{\frac{1}{\beta^{\prime}}}\right\}}\right]
$$

Next, the logarithm of the fractional count value $\left(-\log _{10} \mathrm{~N}_{\mathrm{t}} / \mathrm{N}_{\mathrm{PE}}\right)$ was recalculated using Equation (2) at the average value of $\delta^{\prime}$ $\left(\delta^{\prime}\right.$ avg, $\left.\min \right)$ for the relevant $P-T$ combination. For each species, the value of $\beta^{\prime}$ was varied from 0 to 2 and the value with the minimum cumulative sum of the square of errors (SSE; according to Eq. 4) was designated as the uniform $\beta$ for the entire $P-T$ domain tested.

$$
S E=\sum\left[\left(\log _{10} \frac{N_{t}}{N_{P E}}\right)_{\delta_{\text {avg }}^{\prime}}-\left(\log _{10} \frac{N_{t}}{N_{P E}}\right)_{\text {experimental }}\right]^{2}
$$

After fixing the $\beta$ value at a single value for the entire $P-T$ domain, the $\delta$ values were recalculated for all the conditions tested. Analogous to thermal death kinetics, using $\delta$ to represent the decimal reduction time ( $D$-value, $\mathrm{min})$, the rate of destruction $\left(k, \min ^{-1}\right)$ was calculated according to Equation (5).

$$
k=\left(\frac{2.303}{\delta^{\beta}}\right)^{\frac{1}{\beta}}
$$

\section{A E.coli}
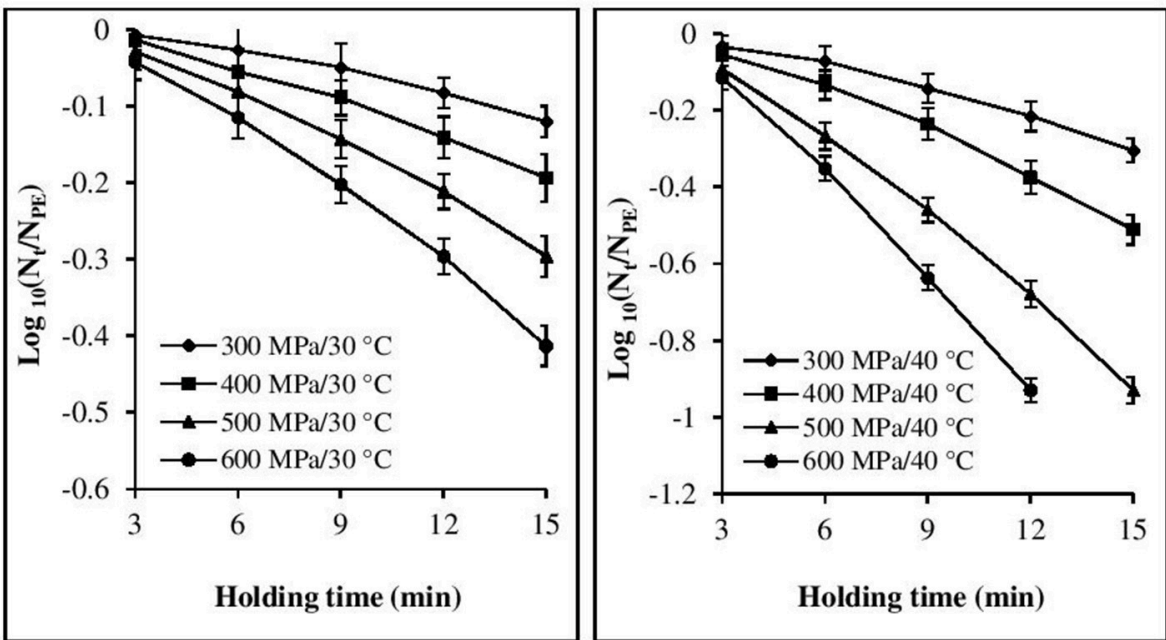

\section{B L. innocua}
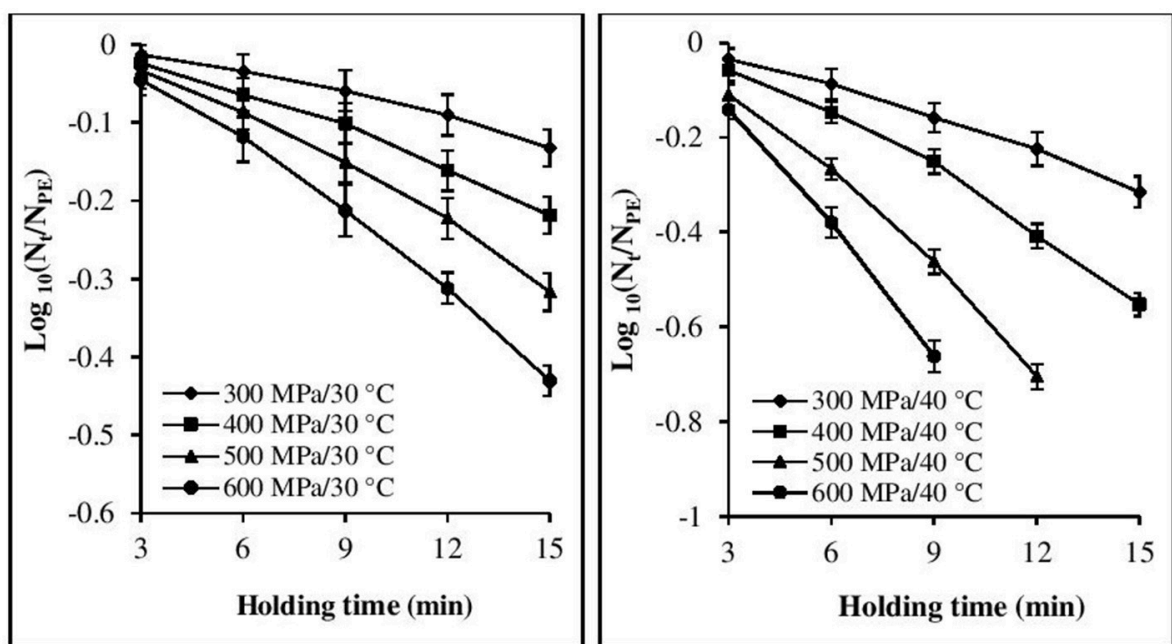

FIGURE 1 | Effect of different pressure-temperature treatments on the inactivation of (A) E. coli and (B) L. innocua in black tiger shrimp. 
The pressure sensitivity of $k$ at a fixed temperature was quantified using the activation volume $\left(V_{a}, \mathrm{~cm}^{3} \mathrm{~mol}^{-1}\right)$, which was calculated using the Eyring equation (Equation 6).

$$
\operatorname{Ln} k=\operatorname{Ln} k_{r e f, P}+\frac{V_{a}}{R T}\left[P_{r e f}-P\right]
$$

where $k_{r e f, P}$ is the rate constant $\left(\mathrm{min}^{-1}\right)$ at the reference pressure, $P_{\text {ref }}(450 \mathrm{MPa}$, the midpoint of the pressure axis).
The temperature sensitivity of $k$ at a fixed pressure was quantified using the activation energy $\left(E_{a}, \mathrm{~kJ} \mathrm{~mol}^{-1}\right)$. This was calculated using the Arrhenius equation (Equation 7) in which the logarithmic function of $k$ is directly proportional to the reciprocal of the absolute temperature $(T, \mathrm{~K})$.
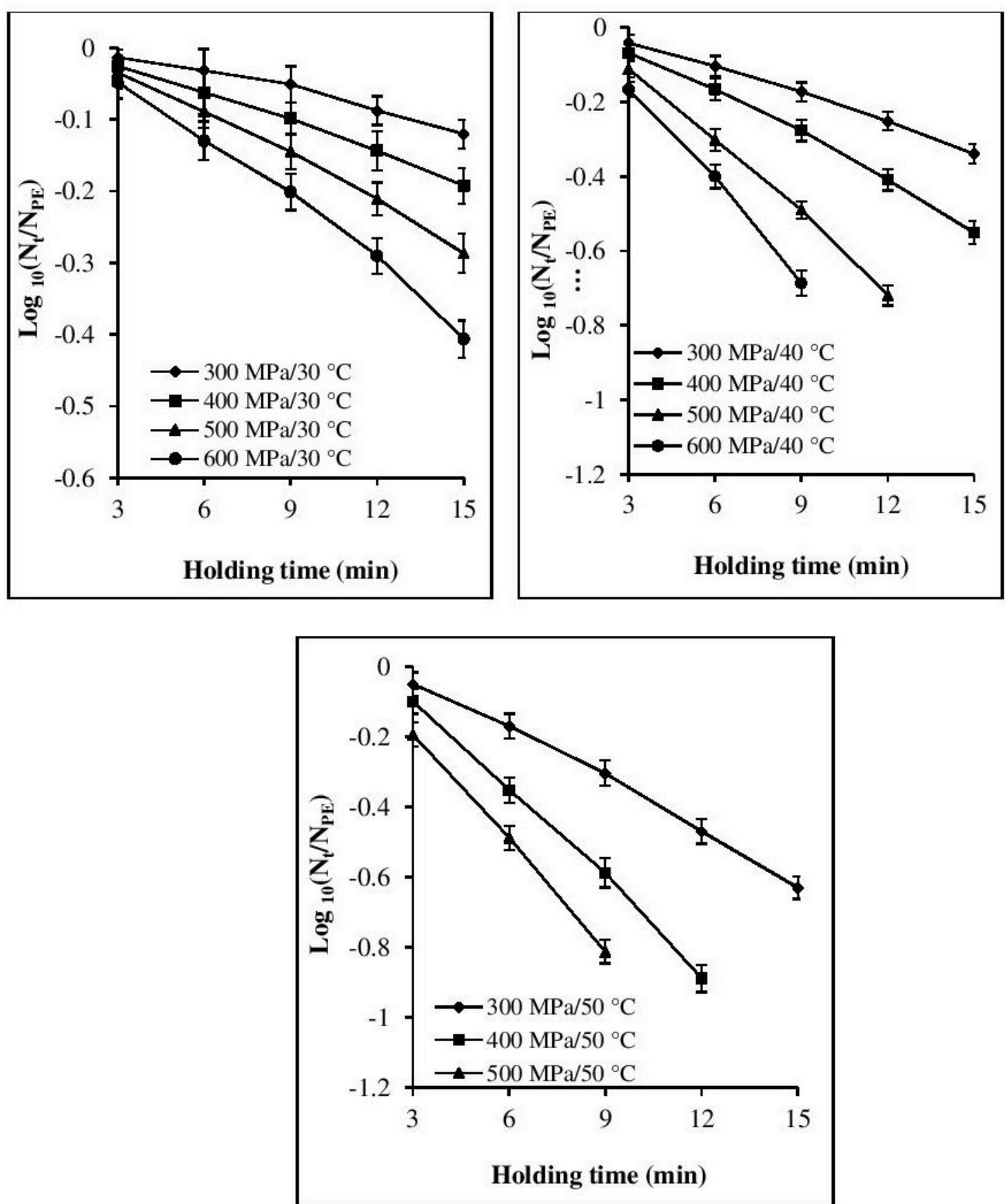

FIGURE 2 | Effect of different pressure-temperature treatments on the inactivation of S. aureus in black tiger shrimp. 
where $k_{r e f, T}$ is the rate constant $\left(\mathrm{min}^{-1}\right)$ at the reference temperature, $T_{\text {ref }}(318 \mathrm{~K}$, the midpoint of the temperature axis).

The regression analyses for calculating the rate constants, $V_{\mathrm{a}}, E_{a}, \mathrm{SSE}$, and regression coefficients $\left(R^{2}\right)$ were performed in Microsoft Excel 2007 (Microsoft Corp., USA). Non-linear curve fitting for $k$ as a function of $V_{a}$ or $E_{\mathrm{a}}$ was performed using Origin Pro version 8.0.

\section{Statistical Analysis}

An analysis of variance (ANOVA) was carried out using SPSS for Windows version 17 (SPSS Inc., Chicago, IL, USA). The difference between the pairs of means was evaluated using Tukey's test, with a $P$-value $<0.05$ being considered statistically significant.

\section{RESULTS AND DISCUSSION Effect of Single-Pulse Pressurization}

A significant SPPE $(P<0.05)$ was observed, both with increases in pressure and temperature, indicating the efficacy of singlepulse pressurization for lowering microbial counts (Table 1). For processing parameters of $300-600 \mathrm{MPa} / 30-60^{\circ} \mathrm{C}$, the SPPE values ranged from 0.90 to $4.29 \log _{10}$ cycles, 0.88 to $4.39 \log _{10}$ cycles, and 0.75 to $5.61 \log _{10}$ cycles for E. coli, L. innocua, and $S$. aureus, respectively. The effect of temperature was observed to be statistically more significant $(P<0.05)$ than that of pressure. Among the three microorganisms studied, E. coli exhibited the greatest sensitivity to single-pulse pressure, followed by $L$. innocua and lastly S. aureus. Ramaswamy et al. (2008) reported similar findings, with greater inactivation by pulse pressurization of E. coli O157:H7 compared to L. monocytogenes Scott A.
The reductions in the bacterial counts induced by singlepulse pressurization were due to the formation of cavitation voids in the bacterial cells as a result of rapid pressurization and depressurization, which led to physical disruption and death of the bacteria (Hiremath and Ramaswamy, 2011). The amount of disruption to the cell wall is dependent on the processing conditions (Ramaswamy et al., 2003). The depressurization magnitude has been reported to have a greater effect on the cell wall than the pressurization magnitude (Hayakawa et al., 1994). The increase in pressure come up time (i.e., the time required to reach the desired pressure) caused the microorganisms to be exposed to pressurization stress for an extra period of time, which increased the extent of inactivation. In addition, the greater reduction in bacterial counts at higher temperature was due to thermal lethality, which thus aided the damage caused by the pressure treatment (Chakraborty et al., 2014).

\section{Isobaric-Isothermal Inactivation Kinetics of Pathogens}

The inactivation rate increased with increases in each of the three processing parameters, viz. pressure, temperature, and time (Figures 1, 2). The inactivation rates of the three pathogens during isobaric-isothermal cycles decreased in the following order: $L$. innocua $>$ E. coli $>$ S. aureus. Several researchers have also reported that $S$. aureus was the most baro-resistant pathogen in their studies (Yuste et al., 2004; Jofré et al., 2009; Cebrián et al., 2016).

At $30^{\circ} \mathrm{C}$, the reduction in the count of all three pathogens was $<5 \mathrm{Log} \mathrm{CFU} \mathrm{g}^{-1}$. The maximum inactivation, $5 \mathrm{Log} \mathrm{CFU}$ $\mathrm{g}^{-1}$ was obtained for L. innocua at $600 \mathrm{MPa} / 15 \mathrm{~min}$. S. aureus

TABLE 2 | Shape factor $\left(\beta_{l}, \beta^{\prime}\right.$, and $\left.\beta\right)$ obtained after model fitting at different pressure-temperature combinations for different microorganisms in black tiger shrimp.

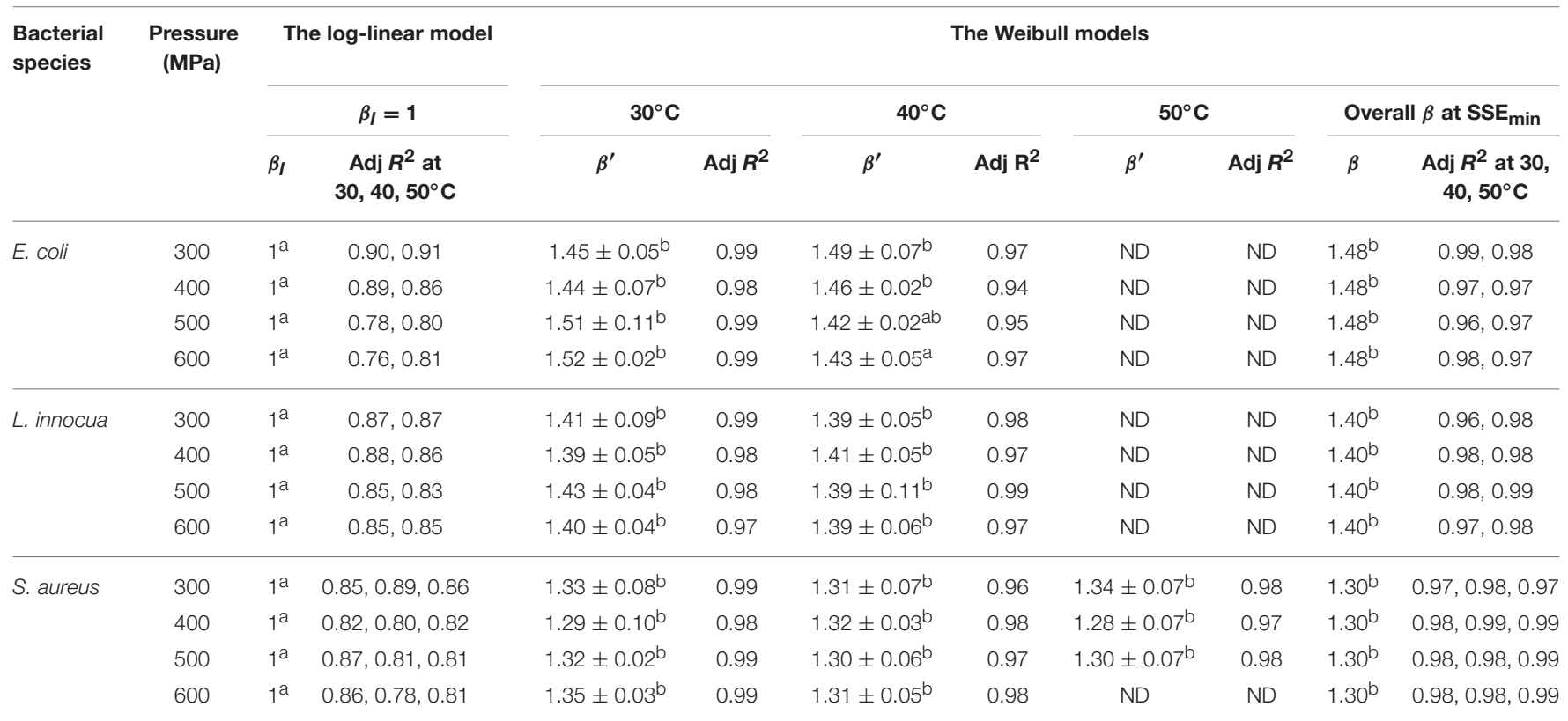

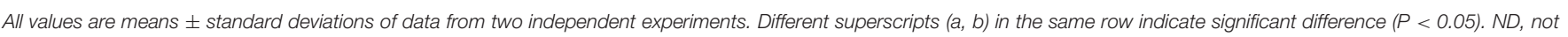
determined. 
exhibited the highest resistance to pressure, as a minimum processing intensity of $500 \mathrm{MPa} / 9 \mathrm{~min} / 50^{\circ} \mathrm{C}$ was required for its complete destruction. However, in the case of L. innocua, no detectable levels were observed after treatment at $500 \mathrm{MPa} / 15$ $\mathrm{min} / 40^{\circ} \mathrm{C}$ and $600 \mathrm{MPa} / 12-15 \mathrm{~min} / 40^{\circ} \mathrm{C}$. In contrast, E. coli was completely destroyed at $600 \mathrm{MPa} / 15 \mathrm{~min} / 40^{\circ} \mathrm{C}$. At $50^{\circ} \mathrm{C}$, neither organism was detected for any of the pressure-holding time conditions. Enhancement of pathogen viability loss with increases in pressure and temperature has been reported for multiple products, including broth (Alpas et al., 2000), milk (Gao and Jiang, 2005), juices (Van Opstal et al., 2003; Bayindirli et al., 2006), and ham (Tassou et al., 2008). The inactivation rates achieved in these studies varied due to the differences in treatment conditions, bacterial strain, test substrate, and enumeration medium.

\section{Model Fitting for the Isobaric Period}

Visual inspection of the isothermal-isobaric inactivation kinetic curves of the studied pathogens suggested that the curves were non-linear $(\beta \neq 1)$ in most cases (Figures 1, 2). Therefore, fitting a straight line to the data points was deemed inappropriate as it would result in considerable errors. Non-linearity in the survival curve might arise from the adaptability of bacterial subpopulations, with variable resistance to the applied stress, which also depends on the surrounding conditions (Bevilacqua et al., 2015).

At all the $P-T$ combinations, the logarithmic survival curves showed the same trend, with downward concavity $\left(\beta^{\prime}>1\right)$. The downward concavity suggested that the microbial cells became less resistant with increased pressure-hold periods, which might be due to the separation of the bacterial cells into clumps (Chakraborty et al., 2015). Based on the minimum SSE values obtained, the $\beta$ values were set at $1.48,1.4$, and 1.3 for $E$. coli, L. innocua, and $S$. aureus, respectively, for the entire $P_{-}$ $T$ domain used in the study. The $\beta$ values were significantly different $(p<0.05)$ from $\beta_{l}$; however, there was no significant difference in comparison to $\beta^{\prime}$ (Table 2). Using fixed $\beta$ values resulted in simpler models, and the reduction in the number of parameters is expected to have resulted in more reliable predictions.

TABLE 3 | Comparison of goodness-of-fit of linear and Weibull models for the survival curves of E. coli, L. innocua and S. aureus in black tiger shrimp.

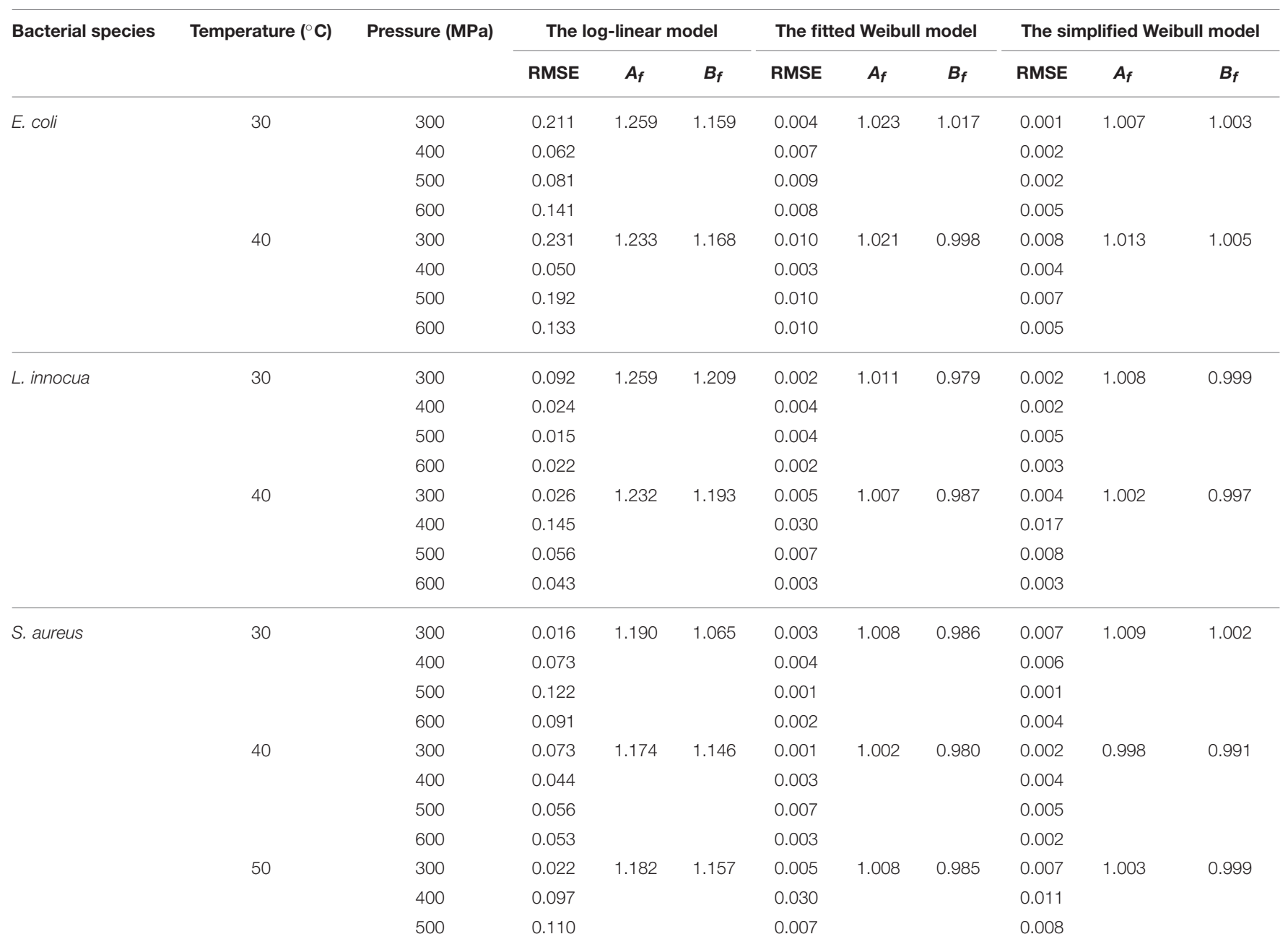


The comparison of the model parameters obtained for the log-linear and both Weibull models at different temperatures is presented in Tables 2, 3. The simplified Weibull model produced fits comparable to the original Weibull model. The goodness of fit of the models was compared by computing the adjusted $R^{2}$ and RMSE, along with the accuracy factor $\left(A_{f}\right)$ and bias factor $\left(B_{f}\right)$ (Ross, 1996), which are shown in Equations (8) and (9), respectively, in which $N$ represents the number of $k$-values estimated.

$$
\begin{aligned}
& A_{f}=10 \frac{\sum\left|\log \left(\frac{k_{\text {predicted }}}{k_{\text {observed }}}\right)\right|}{N} \\
& B_{f}=10 \frac{\sum \log \left(\frac{k_{\text {predicted }}}{k_{\text {observed }}}\right)}{N}
\end{aligned}
$$

Generally, higher $R^{2}$ values, smaller RMSE values, and $A_{f}$ and $B_{f}$ values that are closer to 1 indicate a better model fit. When $\beta^{\prime}$ was fixed at 1 for the entire $P-T$ domain, the adjusted $R^{2}$ for all the microbial groups varied between 0.76 and 0.91 . In contrast, the fitted Weibull curves each had an adjusted $R^{2} \geq 0.94$ and very small RMSE values (the maximum, 0.03, was obtained for both $L$. innocua and S. aureus). However, the simplified Weibull models had adjusted $R^{2}$ and RMSE values ranging from 0.97 to 0.99 and 0.001 to 0.017 , respectively.

The adequacy of the model fitting was investigated using residual plots (Figure 3 ) and calculating the correlation between the predicted and experimental values for the linear and nonlinear models at the fixed $\beta$ values (Figure 4). Residual plots indicate whether a model is fully appropriate for the data being analyzed. The residual plots strongly suggested that the linear regression function was not appropriate, as there was curvature
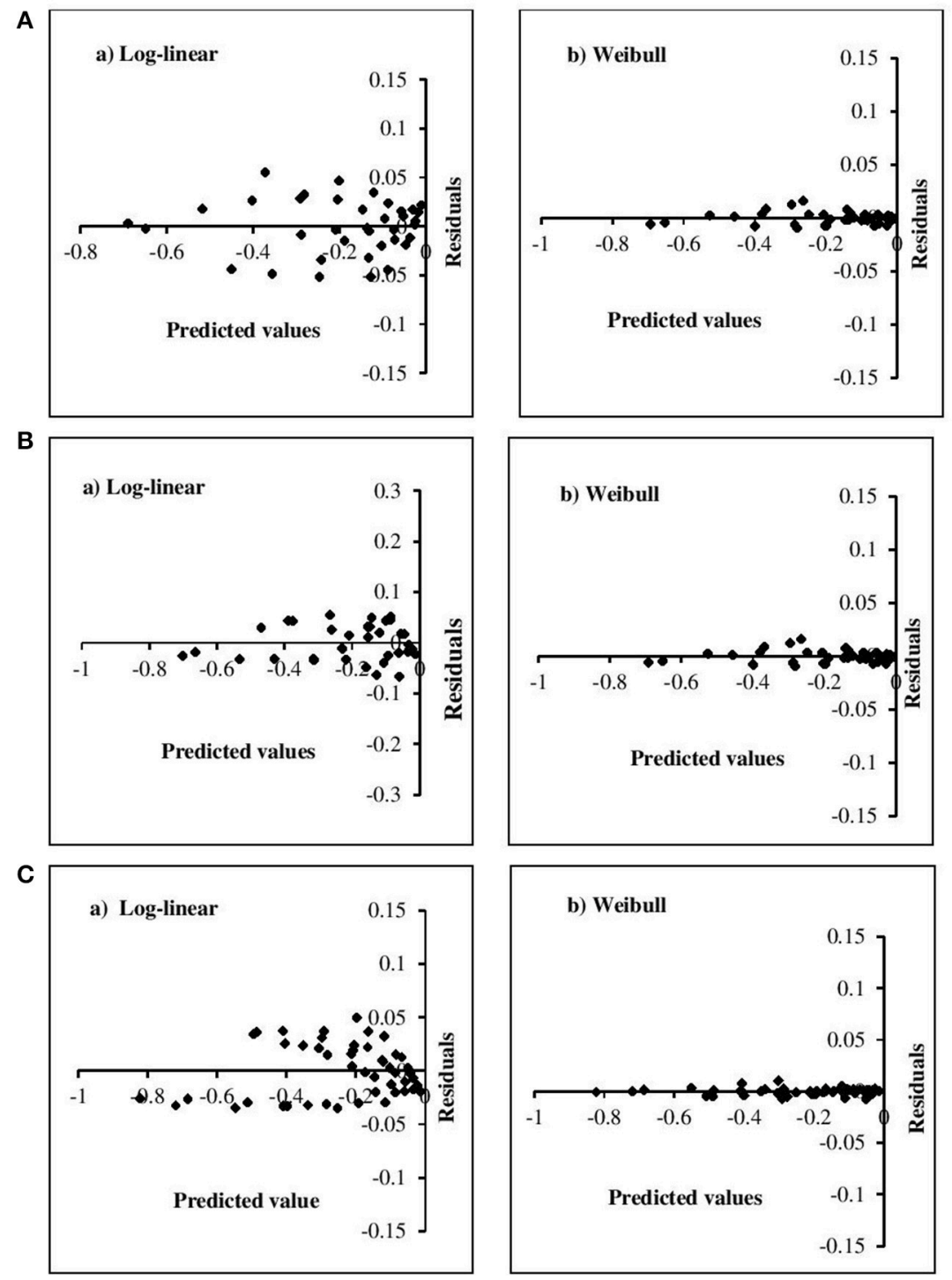

FIGURE 3 | Residual plots for the inactivation of (A) E. coli, (B) L. innocua, (C) S. aureus for log-linear and simplified Weibull model. 
A

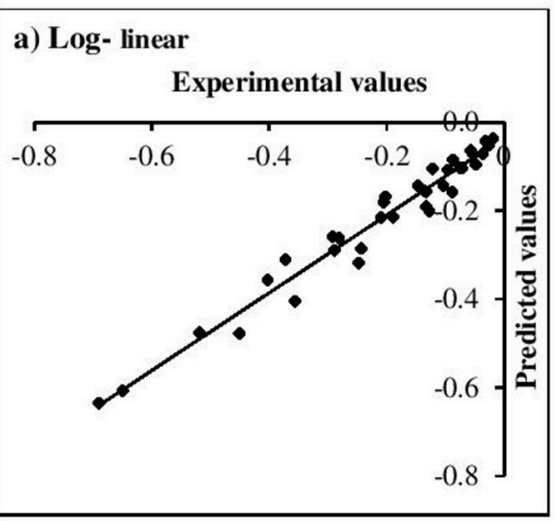

B

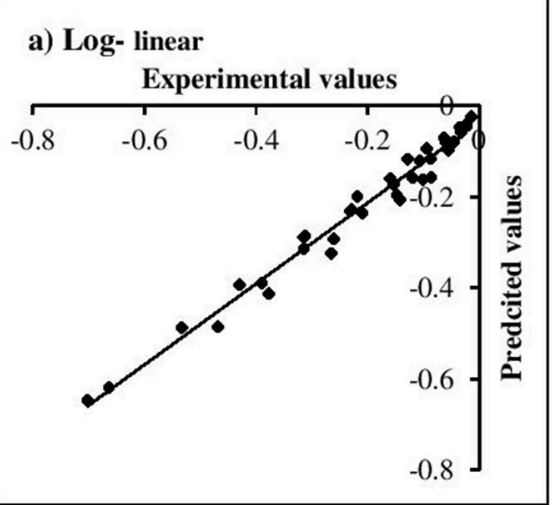

C

a) Log- linear

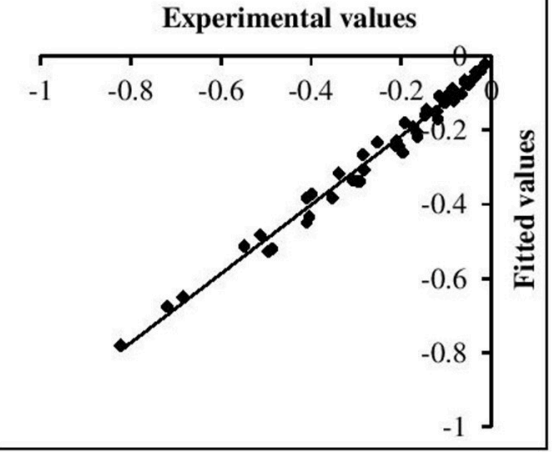

b) Weibull

Experimental values

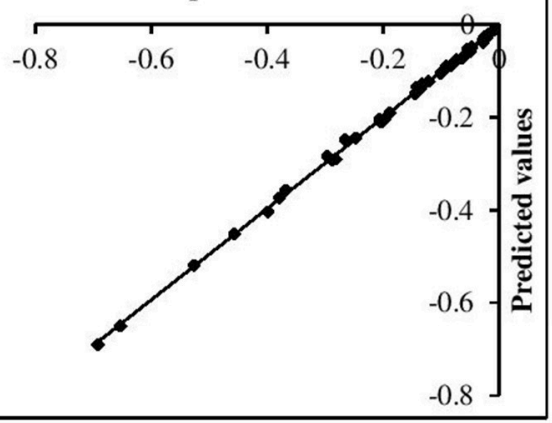

b) Weibull

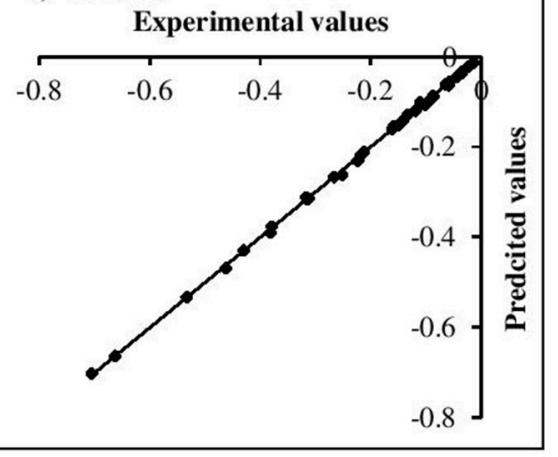

b) Weibull

Experimental values
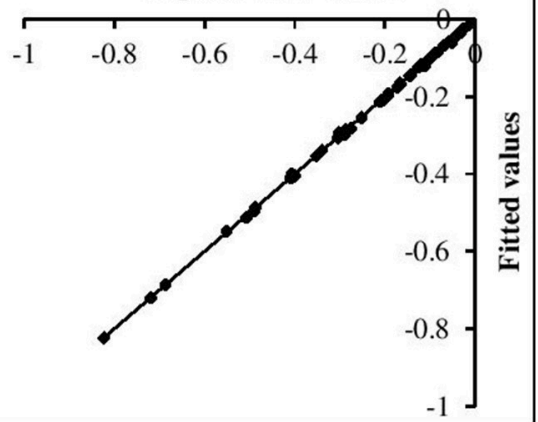

FIGURE 4 | Correlation between experimental and predicted values for (A) E. coli, (B) L. innocua, (C) S. aureus for log-linear and simplified Weibull model.

in the data and the residuals departed from 0 in a systematic fashion. However, for the non-linear models, the residuals were distributed randomly, falling within a horizontal band centered around 0 . Moreover, the correlation between the predicted and experimental values also indicated a close relationship between these values for the non-linear models, which proved to be more appropriate than the log-linear models. In addition, the Weibull model has previously been successfully used to describe microbial kinetics for various HPP products (Van Opstal et al., 2003; Pilavtepe-Çelik et al., 2009; Serment-Moreno et al., 2016), with the inactivation curves demonstrating upward or downward concavity.

\section{Effect of HPP on the Scale Parameter ( $\delta$ ) and Rate Constant (k)}

The deviation of the refitted scale parameters ( $\delta$ values) from the corresponding $\delta^{\prime}$ values was also investigated (Table 4). At the fixed $\beta$ values, the $\delta$ values for all three pathogens were almost comparable to the $\delta^{\prime}$ values. However, at $\beta$ $=1$, the difference between the $\delta_{l}$ and $\delta$ values was significant $(P<0.05)$. A non-linear relationship between the $\delta$ values and the applied pressure and temperature was observed. Therefore, using first-order kinetics would lead to an underestimation or overestimation of the decimal reduction time. 


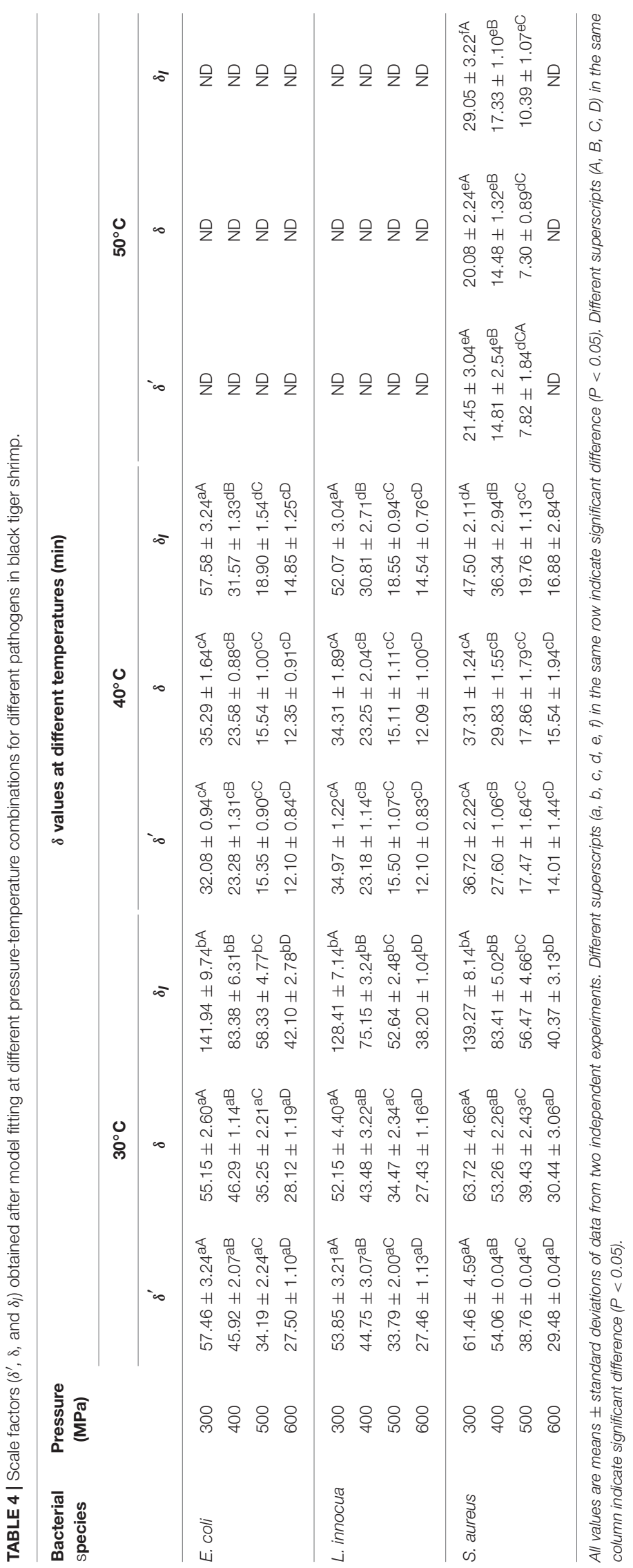


TABLE 5 | Inactivation rate constants, activation volume, and activation energy values for E. coli, L. innocua and S. aureus using Eq. (5-7).

\begin{tabular}{|c|c|c|c|c|c|}
\hline \multirow[t]{2}{*}{ Bacterial species } & \multirow[t]{2}{*}{ Pressure (MPa) } & \multicolumn{3}{|c|}{$k$-value $\left(\times 10^{-2} \mathrm{~min}^{-1}\right)$} & \multirow[t]{2}{*}{$E_{a}\left(\mathrm{~kJ} \mathrm{~mol}^{-1}\right)$} \\
\hline & & $30^{\circ} \mathrm{C}$ & $40^{\circ} \mathrm{C}$ & $50^{\circ} \mathrm{C}$ & \\
\hline \multirow[t]{4}{*}{ E. coli } & 300 & $3.19 \pm 0.11^{\mathrm{aA}}$ & $4.98 \pm 0.27^{\mathrm{bA}}$ & ND & $44.63 \pm 2.11^{\mathrm{A}}$ \\
\hline & 400 & $3.80 \pm 0.47^{\mathrm{aAB}}$ & $7.46 \pm 0.69^{\mathrm{bAB}}$ & ND & $47.87 \pm 3.24^{\mathrm{A}}$ \\
\hline & 500 & $4.99 \pm 0.31^{\mathrm{aBC}}$ & $11.31 \pm 1.37^{\mathrm{bBC}}$ & ND & $61.75 \pm 4.46^{\mathrm{B}}$ \\
\hline & 600 & $6.31 \pm 0.66^{\mathrm{aC}}$ & $14.23 \pm 1.89^{b C}$ & ND & $64.71 \pm 5.04^{\mathrm{B}}$ \\
\hline$-V_{a}\left(\mathrm{~cm}^{3} \mathrm{~mol}^{-1}\right)$ & & $5.65 \pm 0.04^{a}$ & $8.11 \pm 0.04^{b}$ & ND & \\
\hline \multirow[t]{4}{*}{ L. innocua } & 300 & $3.48 \pm 0.68^{\mathrm{aAB}}$ & $5.29 \pm 0.41^{\mathrm{bA}}$ & ND & $46.92 \pm 3.21^{\mathrm{aA}}$ \\
\hline & 400 & $4.17 \pm 0.39^{\mathrm{aAB}}$ & $7.81 \pm 0.79^{\mathrm{bAB}}$ & ND & $50.46 \pm 6.84^{\mathrm{aA}}$ \\
\hline & 500 & $5.26 \pm 0.56^{\mathrm{aBC}}$ & $12.01 \pm 0.83^{\mathrm{bBC}}$ & ND & $63.26 \pm 4.96^{\mathrm{aB}}$ \\
\hline & 600 & $6.62 \pm 0.62^{\mathrm{bC}}$ & $15.01 \pm 1.75^{\mathrm{bC}}$ & ND & $65.89 \pm 3.13^{a B}$ \\
\hline$-V_{a}\left(\mathrm{~cm}^{3} \mathrm{~mol}^{-1}\right)$ & & $6.30 \pm 0.24^{a}$ & $9.11 \pm 0.51^{b}$ & ND & \\
\hline \multirow[t]{4}{*}{ S. aureus } & 300 & $2.98 \pm 0.16^{\mathrm{aA}}$ & $5.09 \pm 0.59^{b A}$ & $9.46 \pm 1.13^{\mathrm{aA}}$ & $39.77 \pm 1.93^{\mathrm{aC}}$ \\
\hline & 400 & $3.57 \pm 0.39^{a A B}$ & $6.37 \pm 0.48^{\mathrm{bA}}$ & $13.12 \pm 1.42^{\mathrm{aA}}$ & $41.95 \pm 2.76^{\mathrm{aAC}}$ \\
\hline & 500 & $4.82 \pm 0.87^{\mathrm{aBC}}$ & $10.64 \pm 0.93^{\mathrm{bBC}}$ & $26.02 \pm 2.18^{\mathrm{aB}}$ & $52.90 \pm 4.45^{\mathrm{aD}}$ \\
\hline & 600 & $6.15 \pm 0.82^{\mathrm{aC}}$ & $12.23 \pm 1.01^{\mathrm{bBC}}$ & ND & $63.12 \pm 6.59^{a B}$ \\
\hline$-V_{a}\left(\mathrm{~cm}^{3} \mathrm{~mol}^{-1}\right)$ & & $5.04 \pm 0.87^{a}$ & $7.81 \pm 1.04^{b}$ & $11.43 \pm 2.16^{c}$ & \\
\hline
\end{tabular}

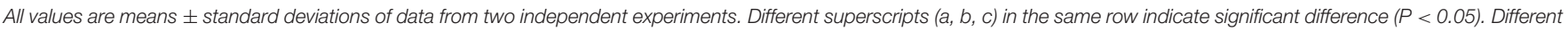
superscripts $(A, B, C, D)$ in the same column indicate significant difference $(P<0.05)$. ND not determined.

An increase in pressure resulted in a reduction in $\delta$ for all three pathogens. Similarly, at constant pressure, an increase in temperature led to a decrease in $\delta$. The reduction in $\delta$ values with increasing pressure and temperature revealed that both parameters contributed additively or synergistically to the death of the bacteria. Increased pressure combined with increased temperature targets many factors in microbial cells rather a single factor, such as, membranes, ribosomes, nucleic acids, proteins (such as, enzymes), and so on. Hence, it is hard to separate the individual lethality of each processing parameter (Smelt et al., 2001).

The death rate constant $\left(k, \min ^{-1}\right)$ for the three pathogens was dependent on both pressure and temperature. The pressure sensitivity of E. coli, L. innocua, and $S$. aureus were estimated using the activation volume, $V_{a}$. The $V_{a}$ in microbial death kinetics represents the formation rates of an activated complex or the quasi-state equilibrium that is generally favored by compaction (Chakraborty et al., 2015). The decrease in $V_{\text {a }}$ with increased temperature suggested an additive or synergistic effect of pressure and temperature on the microbial death rate. At all temperatures, the $V_{a}$ values were negative, ranging between -5.65 and $-8.11 \mathrm{~cm}^{3} \mathrm{~mol}^{-1}$ for E. coli, -6.30 and $-9.11 \mathrm{~cm}^{3}$ $\mathrm{mol}^{-1}$ for L. innocua, and -5.04 and $-11.43 \mathrm{~cm}^{3} \mathrm{~mol}^{-1}$ for $S$. aureus (Table 5). This indicates that pressure has a lethal effect on the pathogens. In general, a large negative $V_{\mathrm{a}}$ value signifies a higher responsiveness to changes in pressure (Mussa et al., 1999). In the current study, the $V_{\mathrm{a}}$ values became more negative with increase in temperature, indicating that the pathogens became more responsive to pressure changes at increasing temperatures.

The temperature sensitivity of all three pathogens was estimated by computing the activation energy, $E_{a}$, at fixed pressures. The $E_{a}$ values increased from 44.63 to $64.71 \mathrm{~kJ} \mathrm{~mol}^{-1}$,
46.92 to $65.89 \mathrm{~kJ} \mathrm{~mol}^{-1}$, and 39.77 to $63.12 \mathrm{~kJ} \mathrm{~mol}^{-1}$ for $E$. coli, L. innocua, and $S$. aureus, respectively, as the pressure was increased from 300 to $600 \mathrm{MPa}$ (Table 5). This signified that the temperature sensitivity of the pathogens is higher at higher pressures. At lower pressures (300-400 MPa), the $E_{a}$ values for the three pathogens were not significantly different $(P \geq 0.05)$. Similarly, no significant difference in the $E_{a}$ values $(P \geq 0.05)$ was observed for pressure treatments of 500 and $600 \mathrm{MPa}$. The temperature sensitivity of the inactivation rate within a particular temperature domain varies considerably between species and even between bacterial strains. Previous studies have revealed that the temperature sensitivity (according to $E_{a}$ values) of the inactivation rate of various microorganisms varied greatly at different pressures (Alpas et al., 1999; vanBoekel, 2002). The higher $V_{\mathrm{a}}$ and lower $E_{a}$ values obtained in the present study might be due to the separation of the SPPE from the pressurehold effect, which was not investigated in the earlier studies.

\section{CONCLUSIONS}

In this study, the effects of high pressure and temperature on the inactivation kinetics of E. coli, L. innocua, and S. aureus in black tiger shrimp were investigated. An additive or synergistic effect of pressure and temperature on the inactivation of the pathogens was noticed in the ranges of processing parameters studied. $S$. aureus was found to be the most baro-resistant species among the three pathogens. The minimum processing intensity required for complete destruction of $S$. aureus was $500 \mathrm{MPa} / 9 \mathrm{~min} / 50^{\circ} \mathrm{C}$. The study showed that the sensitivity of the microorganisms to the applied conditions was different during single-pulse and pressure-hold pressurization. The methodology used in this study could be used to develop a simplified Weibull models to 
describe and predict non-linear survival curves of bacteria in other foods and of other microorganisms. Accurate prediction of survival curves at different pressures and temperatures would be beneficial to the food industry in terms of optimum selection of processing conditions to achieve the desired levels of bacterial inactivation, while also minimizing the production costs and maintaining a high degree of nutritional quality and good flavor and texture.

\section{CHEMICALS USED IN THIS STUDY}

Propylene glycol (PubChem CID: 1030).

Peptone (bacteriological) (PubChem CID: 9257).

\section{REFERENCES}

Ahn, J., Balasubramaniam, V. M., and Yousef, A. E. (2007). Inactivation kinetics of selected aerobic and anaerobic bacterial spores by pressureassisted thermal processing. Int. J. Food Microbiol. 113, 321-329. doi: 10.1016/j.ijfoodmicro.2006.08.012

Alpas, H., Kalchayanand, N., Bozoglu, F., and Ray, B. (2000). Interactions of high hydrostatic pressure, pressurization temperature and $\mathrm{pH}$ on death and injury of pressure-resistant and pressure sensitive strains of foodborne pathogens. Int. J. Food Microbiol. 60, 33-42. doi: 10.1016/S0168-1605(00) 00324-X

Alpas, H., Kalchayanand, N., Bozoglu, F., Sikes, A., Dunne, C. P., and Ray, B. (1999). Variation inresistance to hydrostatic pressure among strains of foodborne pathogens. Appl. Environ. Microbiol. 65, 4248-4251.

APHA, (2001). "Enterobacteriaceae, coliforms, and Escherichia coli as quality and safety indicators Staphylococcus aureus Listeria monocytogenes," in Compendium of Methods for the Microbiological Examination of Foods, eds F. P. Downes and K. Ito (Washington, DC: American Public Health Association), 69-82, 105-115, 437-463.

Anang, D. M., Rusul, G., Bakar, J., and Ling, F. H. (2007). Effects of lactic acid and lauricidin on the survival of Listeria monocytogenes, Salmonella Enteritidis and Escherichia coli $\mathrm{O} 157: \mathrm{H} 7$ in chicken breast stored at $4^{\circ} \mathrm{C}$. Food Control 18, 961-969. doi: 10.1016/j.foodcont.2006.05.015

Balasubramaniam, V. M., Farkas, D. F., and Turek, E. (2008). Preserving foods through high-pressure processing. Food Technol. 62, 32-38.

Basak, S., Ramaswamy, H. S., and Piette, J. P. G. (2002). High pressure destruction kinetics of Leuconostocmesenteroides and Saccharomyces cerevisiae in single strength and concentrated orange juice. Innov. Food Sci. Emerg. Technol. 3, 223-231. doi: 10.1016/S1466-8564(02)00008-5

Bayindirli, A., Alpas, H., Bozoglu, F., and Hizal, M. (2006). Efficiency of high pressure treatment on inactivation of pathogenic microorganisms and enzymes in apple, orange, apricot and sour cherry juices. Food Control 17, 52-58. doi: 10.1016/j.foodcont.2004.09.002

Bevilacqua, A., Speranza, B., Sinigaglia, M., and Corbo, M. R. (2015). A focus on the death kinetics in predictive microbiology: benefits and limits of the most important models and some tools dealing with their application in foods. Foods 4, 565-580. doi: 10.3390/foods4040565

Buzrul, S., and Alpas, H. (2004). Modeling the synergistic effect of high pressure and heat on inactivation kinetics of Listeria innocua: A preliminary study. FEMS Microbiol. Lett. 238, 29-36. doi: 10.1016/j.femsle.2004.07.011

Buzrul, S., Alpas, H., Largeteau, A., and Demazeau, G. (2008). Inactivation of Escherichia coli and Listeria innocua in kiwifruit and pineapple juices by high hydrostatic pressure. Int. J. Food Microbiol. 124, 275-278. doi: 10.1016/j.ijfoodmicro.2008.03.015

Cebrián, G., Ma-as, P., and Condón, S. (2016). Comparative resistance of bacterial foodborne pathogens to non-thermal technologies for food preservation. Front. Microbiol. 7:734. doi: 10.3389/fmicb.2016.00734

Chakraborty, S., Rao, P. S., and Mishra, H. N. (2014). Effect of pH on enzyme inactivation kinetics in high-pressure processed pineapple (Ananascomosus, L.)

\section{AUTHOR CONTRIBUTIONS}

All authors listed have made a substantial, direct and intellectual contribution to the work, and approved it for publication.

\section{FUNDING}

Financial assistance was provided by the National Agricultural Innovation Project (NAIP) of the Indian Council of Agricultural Research (ICAR), which is supported by the World Bank (project code: NAIP/Comp-4/618001, grant number: F. No. NAIP/C4/C30027/2008-09, dated 12/01/09).

puree using response surface methodology. Food Bioprocess. Technol. 7, 3629-3645. doi: 10.1007/s11947-014-1380-0

Chakraborty, S., Rao, P. S., and Mishra, H. N. (2015). Empirical model based on Weibull distribution describing the destruction kinetics of natural microbiota in pineapple (Ananascomosus, L.) puree during high-pressure processing. Int. J. Food Microbiol. 211, 117-127. doi: 10.1016/j.ijfoodmicro.2015.06.017

Chen, H., and Hoover, D. G. (2003). Modeling the combined effect of high hydrostatic pressure and mild heat on the inactivation kinetics of Listeria monocytogenes Scott A in whole milk. Innov. Food Sci. Emerg. Technol. 4, 25-34. doi: 10.1016/S1466-8564(02)00083-8

Dogan, C., and Erkmen, O. (2004). High pressure inactivation kinetics of Listeria monocytogenesinactivation in broth, milk, and peach and orange juices. J. Food Eng. 62, 47-52. doi: 10.1016/S0260-8774(03)00170-5

Fernandez, A., Collado, J., Cunha, L. M., Ocio, M. J., and Mart nez, A. (2002). Empirical model building based on Weibull distribution to describe the joint effect of $\mathrm{pH}$ and temperature on the thermal resistance of Bacillus cereus in vegetable substrate.Int. J. Food Microbiol. 77, 147-153. doi: 10.1016/S0168-1605(02)00046-6

Gao, Y. L., and Jiang, H. H. (2005). Optimization of process conditions to inactivate Bacillus subtilis by high hydrostatic pressure and mild heat using response surface methodology. Biochem. Eng. J. 24, 43-48. doi: 10.1016/j.bej.2005.01.023

Garriga, M., Aymerich, M. T., Costa, S., Monfort, J. M., and Hugas, M. (2002). Bactericidal synergism through bacteriocins and high pressure in a meat model system during storage. Food Microbiol. 19, 509-518. doi: $10.1006 /$ fmic. 2002.0498

Guan, D., Chen, H., Ting, E. Y., and Hoover, D. G. (2006). Inactivation of Staphylococcus aureus and Escherichia coli O157:H7 under isothermal endpoint pressure conditions. J. Food Eng. 77, 620-627. doi: 10.1016/j.jfoodeng.2005.07.021

Hayakawa, I., Kanno, T., Tomita, M., and Figio, Y. (1994). Application of high pressure for spore inactivation and protein denaturation. J. Food Sci. 59, 159-163. doi: 10.1111/j.1365-2621.1994.tb06923.x

Hiremath, N. D., and Ramaswamy, H. S. (2011). High pressure destruction kinetics of spoilage and pathogenic microorganisms in mango juice. J. Food Process. Preserv. 36, 113-125. doi: 10.1111/j.1745-4549.2011.00559.x

Jofré, A., Aymerich, T., Grèbol, N., and Garriga, M. (2009). Efficiency of high hydrostatic pressure at $600 \mathrm{MPa}$ against food-borne microorganisms by challenge tests on convenience meat products. LWT Food Sci. Technol. 42, 924-928. doi: 10.1016/j.lwt.2008.12.001

Kaur, B. P., and Rao, P. S. (2016). Process optimization for high pressure processing of black tiger shrimp (Penaeus monodon) using response surface methodology. Food Sci. Technol. Int. 23, 197-208. doi: 10.1177/1082013216673460

Mussa, D. M., Ramaswamy, H. S., and Smith, J. P. (1999). Ultra high pressure destruction kinetics of Listeria monocytogenes in pork. J. Food Protoc. 62, 165-170. doi: 10.4315/0362-028X-62.1.40

Nicolaides, L. (2009). "Crustacean shellfish," in Microbiology Handbook Fish and Seafood, ed R. Fernandes (Cambridge, UK: Leatherhead Publishing), 79-92.

Panagou, E. Z., Tassou, C. C., Manitsa, C., and Mallidis, G. (2007). Modelling the effect of high pressure on the inactivation kinetics of a 
pressure-resistant strain of Pediococcus damnosus in phosphate buffer and gilt-head seabream (Sparus aurata). J. Appl. Microbiol. 102, 1499-1507. doi: 10.1111/j.1365-2672.2006.03201.x

Pavuluri, S. R., and Kaur, B. P. (2014). "High pressure inactivation kinetics of Escherichia coli in black tiger shrimp (Penaeus monodon)," in International Conference on Biological, Civil and Environmental Engineering (BCEE-2014), (Dubai), 167-169.

Pilavtepe-Çelik, M., Buzrul, S., Alpas, H., and Bozoglu, F. (2009). Development of a new mathematical model for inactivation of Escherichia coli O157:H7 and Staphylococcus aureus by high hydrostatic pressure in carrot juice and peptone water. J. Food Eng. 90, 388-394. doi: 10.1016/j.jfoodeng.2008.06.043

Pushparajan, N., and Soundarapandian, P. (2010). Recent farming of marine black tiger shrimp, Penaeus monodon (Fabricius) in South India. Afr. J. Basic Appl. Sci. 2, 33-36.

Rajan, S., Pandrangi, S., Balasubramaniam, V. M., and Yousef, A. E. (2006). Inactivation of Bacillus stearothermophilus spores in egg patties by pressure-assisted thermal processing. LWT Food Sci. Technol. 39, 844-851. doi: 10.1016/j.lwt.2005.06.008

Ramaswamy, H. S., Riahi, E., and Idziak, E. (2003). High pressure destruction kinetics of E. coli $(29,055)$ in apple juice. J. Food Sci. 68, 1750-1756. doi: 10.1111/j.1365-2621.2003.tb12323.x

Ramaswamy, H. S., Zaman, S. U., and Smith, J. P. (2008). High pressure destruction kinetics of Escherichia coli (O157:H7) and Listeria monocytogenes (Scott A) in fish slurry. J. Food Eng. 87, 99-106. doi: 10.1016/j.jfoodeng.2007.11.017

Rendueles, E., Omar, M. K., Alvseike, O., Alonso-Calleja, C., Capita, R., and Prieto, M. (2011). Microbiological food safety assessment of high hydrostatic pressure processing: a review. Food Sci. Technol. 44, 1251-1260. doi: 10.1016/j.lwt.2010.11.001

Riahi, E., Ramaswamy, H. S., and Idziak, E. (2003). High pressure destruction kinetics of Leuconostoc mesenteroides, Pichia membranafaciens and Zygosaccharomyces bailii in apple juice. Appl. Biotechnol Food Sci. Policy 1, 1-8. doi: 10.1021/bp025667z

Ross, T. (1996). Indices for performance evaluation of predictive models in food microbiology. J. Appl. Bacteriol. 81, 501-508.

Ruiz-Espinosa, H., Amador-Espejo, G. G., Barcenas-Pozos, M. E., AnguloGuerrero, J. O., Garcia, H., and Welti-Chanes, S. J. (2013). Multiplepass high-pressure homogenization of milk for the development of pasteurization-like processing conditions. Lett. Appl. Microbiol. 56, 142-148. doi: 10.1111/lam.12027

Serment-Moreno, V., Barbosa-Ca'novas, G., Torres, J. A., and Welti-Chanes, J. (2014). High-pressure processing: kinetic models for microbial and enzyme inactivation. Food Eng. Rev. 6, 56-88. doi: 10.1007/s12393-014-9075-x

Serment-Moreno, V., Torres, J. A., Fuentes, C., Ríos-Alejandro, J. G., BarbosaCa'novas, G., and Welti-Chanes, J. (2016). Limitations of the log-logistic model for the analysis of sigmoidal microbial inactivation data for high-pressure processing (HPP). Food Bioprocess. Technol. 9, 904-916. doi: 10.1007/s11947-016-1677-2

Smelt, J. P., Hellemons, J. C., and Patterson, M. (2001). "Effects of high pressure on vegetative microorganism," in Ultra High Pressure Treatments of Foods, eds M. E. G. Hendrickx and D. Knorr (New York, NY: Kluwer Academic/Plenum), 55-76. doi: 10.1007/978-1-4615-0723-9_3

Smelt, J. P., Hellemons, J. C., Wouters, P. C., and Van, G. S. J. (2002). Physiological and mathematical aspects in setting criteria for decontamination of foods by physical means. Int. J. Food Microbiol. 78, 57-77. doi: 10.1016/S0168-1605(02)00242-8

Smelt, J. P. P. M. (1998). Recent advances in the microbiology of high pressure processing. Trends Food Sci. Technol. 9, 152-158. doi: 10.1016/S0924-2244(98)00030-2

Tassou, C. C., Panagou, E. Z., Samaras, F. J., Galiatsatou, P., and Mallidis, C. G. (2008). Temperature-assisted high hydrostatic pressure inactivation of Staphylococcus aureus in a ham model system: evaluation in selective and nonselective medium. J. Appl. Microbiol. 104, 1764-1773. doi: 10.1111/j.1365-2672.2007.03698.x

vanBoekel, M. A. J. S. (2002). On the use of the Weibull model to describe thermal inactivation of microbial vegetative cells. Int. J. Food Microbiol. 749, 139-159. doi: 10.1016/S0168-1605(01)00742-5

Van Opstal, I., Vanmuysen, S. C. M., and Michiels, C. W. (2003). High sucrose concentration protects $E$. coli against high pressure inactivation but not against high pressure sensitization to the lactoperoxidase system. Int. J. Food Microbiol. 88, 1-9. doi: 10.1016/S0168-1605(03)00070-9

Wouters, P., Glaasker, E., and Smelt, J. P. P. M. (1998). Effects of high pressure on inactivation kinetics and events related to proton efflux in Lactobacillus plantarum. Appl. Environ. Microbiol. 64, 509-514.

Yuste, J., Capellas, M., Fung, D. Y. C., and Mor-Mur, M. (2004). Inactivation and sublethal injury of foodborne pathogens by high pressure processing: evaluation with conventional media and thin agar layer method. Food Res. Int. 37, 861-866. doi: 10.1016/j.foodres.2004.05.002

Conflict of Interest Statement: The authors declare that the research was conducted in the absence of any commercial or financial relationships that could be construed as a potential conflict of interest.

Copyright (C) 2017 Kaur and Rao. This is an open-access article distributed under the terms of the Creative Commons Attribution License (CC BY). The use, distribution or reproduction in other forums is permitted, provided the original author(s) or licensor are credited and that the original publication in this journal is cited, in accordance with accepted academic practice. No use, distribution or reproduction is permitted which does not comply with these terms. 